\title{
THE EFFECT OF USING GENRE-BASED APPROACH TOWARDS STUDENTS' WRITING SKILL ON RECOUNT TEXT
}

\author{
Devia Della Dhika ${ }^{1}$, Muhammad Sulhan² \\ ${ }^{1,2}$ Program of English Education, Universitas Indraprasta PGRI \\ Jalan Nangka No. 58C, Jagakarsa, Tanjung Barat, Jakarta Selatan 12530, Indonesia
}

Corresponding Author(S): sulhanmuhammad20@gmail.com

\begin{abstract}
:
The research aims at determining the effect of using Genre-Based Approach towards students' skill on writing recount text at SMP PGRI 9 East Jakarta. It uses quantitative design by giving treatment of the application of Genre-Based Approach to the experiment class. The population was all students of eight graders at SMP PGRI 9 East Jakarta and was taken 50 of them as the samples. They were divided into two classes; the experiment class consists of 25 students and the control class consists of 25 students. The result shows that the mean of the control class is 69.78 , the median is 70 , and the mode is 65.94 with standard deviation values is 7.63 . While, the mean of the experiment class is 81.06, the median is 81.35 and the mode is 101.5 with standard deviation values is 10.1 . The $\mathrm{F}_{\text {observed }}$ is $1.78<\mathrm{F}_{\text {table }} 1.98$, meaning that both classes are homogenous. The hypothesis test $\mathrm{t}_{\text {observed }}$ is $4.44>\mathrm{t}_{\text {table }} 2.01$, which means that $\mathrm{H} 1$ is accepted which confirms there is an effect of using Genre-Based Approach towards students' writing skill on recount text at SMP PGRI 9 East Jakarta
\end{abstract}

Keywords:

Genre-based, Approach, Writing skill, Recount text

\section{INTRODUCTION}

English as the first international language accepted in the world making English as a compulsory lesson for several countries including Indonesia. In the Indonesian context, English is used as a foreign language and is a compulsory lesson that must be tested on the National Exam for junior high school and senior high school. Some important purposes for Indonesian students to learn English are; to get the opportunity to work more broadly; to expand relationship; to make the work easier specially to operate computer; to increase knowledge, and so forth.

According to Crystal (2003:5), "English is a global language as it can be heard on television spoken by politicians from all over the world, on signs and advertisement or in the restaurant menu". Broughton, et. al. (2002:6) state differently that "English is the language of the mass media: newspaper, radio, and television in a second language situation. In addition, English is also used in the language of official institutions - of a low court at local and central government - and of education". Therefore, English is an 
important foreign language that should be learned by the student especially in Indonesia because there are many benefits by learning English. It is not only about how to speak English fluently but also about grammatical rules while they want to write by using English.

There are four basic skills in language learning; listening, reading, speaking, and writing. They stand alone or are separate yet bound or attached altogether. These all skills should be repeatedly handled in a way that helps students meet the standard set for them and develop their communicative competence (Sadiku, 2015). Teachers face a challenging task to deliver each of the skill ellaborately and, hence, arrange teaching strategy to students. The target achievement desire should be expressed in the form of explicit formulations about the expectations of change that are formed in students through education process (Sulhan, 2019).

In the case of writing aspect, Lyons and Heasly (2006:13) affirm that "Writing is clearly a complex process, and complement writing is frequently accepted as being the last language skill to be acquired for native speakers of the language as well as for those learning a foreign/second language". It belongs to the indirect communication that conveys meaningful and expressive information from the author to the readers in the form of written texts. Harmer (2004:31) assures that "Writing enables students to focus on accurate language usage as their effort of thinking and writing at once". It may well generate language development as the writing puts into their minds. It means that writing activity can develop students' mindset of the English language in use.

Writing skill is usually linked with composing learning. Students often encounter impediments and hurdles in composing their texts for particular essay or text type such as narrative, recount, procedure, and descriptive text. Recount text as one of the types of English texts that have to be mastered by junior high school students is the text that retells about something in the past or experience in a chronological order. "Recount text is the simplest text type in this genre, recount structure and grammar are similar with narrative genre that retells past event, usually in order to in which they occurred" (Knap and Watkins, 2005:224). Also, it gives the audience a description of what and when it occurred. The story in recount text has an expression of attitude and feeling usually made by narrators about the even.

Dirgeyasa (2016) affirms that a recount is the retelling an event. Recount text is used for telling about the event, personal experience, factual or historical events, that had happened in the past chronologically. The recount text uses past tense and often past continuous to retell the events. Hence, the students must pay attention to the grammar in order to not making misunderstanding to the readers.

To the success of writing skill achievement, teacher must be able to choose the right approach for teaching writing because every approach has different implementation and result for the student. Genre-Based Approach (GBA) is one of the approaches that can be applied as an alternative in which it guides students to deal with the social aspect, organization, and language feature on any kind of text. According to Nugroho and Hafrizon (2009:4), "Genre-Based Approach is an approach language learning from the perspective of texts requires an accompanying methodology which can enable students to 
develop the knowledge and the skill to deal with spoken and written texts in social contexts". Besides, Ann in Dirgeyasa (2016) explains that teaching and learning writing through Genre-Based Approach is a matter of one coin with two faces. On one side, genre is viewed as a type of writing text and as an approach for teaching and learning writing on the other side. This clearly shows that Genre-Based Approach is absolutely distinctive among other existing approaches in writing.

The cycle of teaching and learning activities in the Genre-Based Approach consists of a number of stages. As explained by Nugroho and Hafrizon (2009:23-25), there are several stages, namely: building the text, modeling and deconstructing the text, joint construction of the text, independent construction of the text, and linking related to the text.

\section{Building the Text}

This stage is aimed: 1) to introduce the social context, 2) to explore feature of the general cultural context, and 3) to explore the immediate context of situation by investigating the register of a model text. In this stage, teacher can apply progressive brainstorming activities such as 1) presenting the context through pictures, audiovisual material, realia, excursions field - trips, and guest speaker, 2) establishing the social purpose trough discussions or surveys, 3 ) doing cross-cultural activities, and 4) comparing the model text with other texts of the same or contrasting type.

\section{Modeling and Deconstructing the Text}

This stage's purpose is to make a discussion about the structural pattern and the language feature of the selected recount model texts by guiding the students to arrange the events in the text through discussion. In this stage, teacher explains the grammar and the text organizations of the particular genre, students are introduced to be familiar with the purpose, the organizations and the language features of a particular genre and several models of the particular genre will be distributed to the students. Teacher can do activities such as presentation and practice activities relating to the grammatical features of the text, oral-aural, pronunciation, decoding, spelling, handwriting or typing practice as needed for the use of the text - type.

\section{Joint Construction of the Text}

In this stage, students begin to build the construction of whole examples of the text type and teacher gradually lessens their help as the students move closer to be able to work and to control the text type independently. This is also the stage of letting students elaborate and exemplify on the knowledge of word meaning and function identification emerging in the selected recount modeling text. Joint construction activities include questioning, discussing and editing the whole class construction, skeleton texts, jigsaw and information gap activities, small group construction of texts, dictation or selfassessment and peer assessment activities.

\section{Independent Construction of the Text}

At this stage, students work independently with the text, but before coming to this stage, the teacher makes sure that students have already got the competencies because students' performances are used for achievement assessment. 


\section{Linking Related to the Text}

This stage is to encourage the class to create different recounts by consulting both construction and the meaning of the modeling text they have read and the productive texts in the independent construction stage. In this stage, students investigate what they have learned by activities such as comparing the use of the text - type to across different fields, researching other text - type used in the same field, or researching how a key language feature used in this text - type is used in other text - type.

All theories discussed above underline the concept of the research and used to support the writer's hypothesis that there is an effect of using Genre-Based Approach towards students' skill in writing recount text at SMP PGRI 9, Cipayung, East Jakarta.

\section{METHOD}

This present research used experimental method with quantitative data. In this case, the writer needs to measure the relation between variables as well as to determine whether one variable might affect or influence another variable. This research was conducted at SMP PGRI 9 Cipayung, East Jakarta, from May 9 to 14, 2019. The design of this research was categorized as true experimental design by using the form of post-test control group design. The research sample was 50 students of the eighth graders at SMP PGRI 9 that was divided into 2 groups, they are: experiment group consisting of 25 students and control group consisting of 25 students. This research used a non-probably sampling and it did not need any type of random selection from a population.

Based on the method of the research above, there are two variables involved; the independent variable: the use of Genre-Based Approach and the dependent variable: students' skill in writing recount text at SMP PGRI 9, East Jakarta. The research instrument for this research was post-test only. The aim of writing test was to measure the effect of using Genre-Based Approach in writing recount text.

\section{RESULTS AND DISCUSSION}

In this research, the data had been collected and were processed by using data description in order to find out the value of mean, median, mode, variance, and standard deviation from both classes.

Table 1 Data Description

\begin{tabular}{lll}
\hline Value & Control Class $\left(\mathrm{X}^{1}\right)$ & Experiment class $\left(\mathrm{X}^{2}\right)$ \\
\hline Mean & 69.78 & 81.06 \\
Median & 70 & 81.35 \\
Mode & 65.94 & 101.5 \\
Variance & 58.26 & 103.71 \\
Standard Deviation & 7.63 & 10.1 \\
\hline
\end{tabular}

\section{Hypothesis Test}

The writer used t-test to find out whether or not there is an effect of using Genre-Based Approach towards students' writing skill in recount text. According to the hypothesis of this research, the statistic hypothesis can be arranged as below: 
1. $\mathrm{H}_{\mathrm{o}}: \mu_{1}<\mu_{2}$

There is not significant effect of using Genre-Based Approach towards students' writing skill on recount text at SMP PGRI 9.

2. $\mathrm{H}_{1}: \mu_{1}>\mu_{2}$

There is a significant effect of using Genre-Based Approach towards students' writing skill on recount text at SMP PGRI 9.

But because the standard deviation from the control class and the experiment class are different, before using t-test, the writer has to firstly calculate the standard deviation by using the following formula:

$$
\begin{aligned}
S_{\text {gab }} & =\sqrt{\frac{\left(n_{1}-1\right) S_{1}^{2}+\left(n_{2}-1\right) S_{2}^{2}}{n_{1}+n_{2}-2}} \\
S_{\text {gab }} & =\sqrt{\frac{(25-1) 103.71+(25-1) 58.26}{25+25-2}} \\
S_{\text {gab }} & =\sqrt{\frac{2489.04+1398.24}{48}} \\
S_{\text {gab }} & =\sqrt{80.98} \\
S_{\text {gab }} & =8.99
\end{aligned}
$$

The hypothesis test is measured by $\mathrm{t}_{\text {test }}$ with the significance level $\alpha=0.05$, and the formula is as the following:

$$
\begin{aligned}
& t=\frac{\bar{X}_{1}-\bar{X}_{2}}{S_{g a b} \sqrt{\frac{1}{n_{1}}+\frac{1}{n_{2}}}} \\
& t=\frac{81.06-69.78}{8.99} \sqrt{\frac{1}{25}+\frac{1}{25}} \\
& t=\frac{11.28}{8.99} \sqrt{0.08}=\frac{11.28}{2.54} \\
& t=4.44
\end{aligned}
$$

To find out the $\mathrm{t}_{\text {table }}$ value, $\mathrm{dk}$ is nedded with formula:

$\mathrm{dk} \mathrm{n} 1+n 2-28$

$\mathrm{dk} 25+25-2=48$

$\mathrm{t}_{\text {table }}$ value with $\mathrm{dk} 48$ and significant level $\alpha=0.05$ is 2.010

Based on the result of measuring $t_{\text {observed }}$ and $t_{\text {table }}$ above, It shows that the score of $t_{\text {observed }}$ is 4.44 and the score of $t_{\text {table }}$ is 2.010 , it means that $t_{\text {observed }}(4.44)>t_{\text {table }}(2.010)$. It proves that the result of this research hypothesis $\mathrm{H}_{1}: \mu_{1}>\mu_{2}$ is accepted which says "there is an effect of using Genre-Based Approach towards students' writing skill on recount text at SMP PGRI 9".

\section{CONCLUSION}

This research is purposed to examine the effect of Genre-Based Approach towards student's writing skill on recount text of the eighth grade at SMP PGRI 9 East Jakarta. Based on the research results, it can be concluded that there is an effect of using GenreBased Approach towards students' writing skill on recount text of eighth grade. This research shows that teaching writing by using Genre-Based Approach is effective. 


\section{REFERENCE}

Broughton, D., Brumfit, C., Pincas, A., \& Wilde, R. D. (2002). Teaching English As a Foreign Language Second Edition. England: Taylor \& Francis.

Crystal, D. (2003). English As a Global Language. England: Cambridge University Press.

Dirgeyasa, I. (2016). College Academic Writing A Genre-Based Perspective. Jakarta: Kencana.

Harmer, J. (2004). How To Teach Writing. New York: Pearson Longman.

Knapp, P., \& Watkins, M. (2005). Genre, Text, Grammar Technologies for Teaching and Assessing Writing. Sydney: UNSW Press Book.

Lyons, L., \& Heasly, B. (2006). Study Writing-A Course in Writing Skills for Academic Purposes. England: Cambridge University Press.

Nugroho, T., \& Hafrizon. (2009). Introduction to Genre Based Approach. Jakarta: Ministry of National Education

Sadiku, L. M. (2015). The importance of four skills reading, speaking, writing, listening in a lesson hour. European Journal of Language and Literature, 1(1), 29. https://doi.org/10.26417/ejls.v1i1.p29-31

Sulhan, M. (2019). Pemerolehan demensi pengetahuan dalam keterampilan membaca teks bahasa Inggris siswa Sekolah Menegah Atas. Deiksis, 11(01), 69. https://doi.org/10.30998/deiksis.v11i01.3109 